\title{
Novel Gene Mutations in Tunisian Isolate of Avian H9N2 Influenza Virus
}

\author{
Rim Aouini ${ }^{1,2 *}$, Nacira Laamiri ${ }^{1,2}$ and Abdeljelil Ghram ${ }^{1}$ \\ ${ }^{1}$ Laboratory of Epidemiology and Veterinary Microbiology, Pasteur Institute of Tunis, University Tunis El Manar, 13 Place Pasteur, Tunis- Belvedere, Tunisia \\ ${ }^{2}$ Faculty of Sciences Bizerte, University of Carthage, Zarzouna Bizerte, Tunisia
}

\begin{abstract}
A new strain of H9N2 avian influenza virus (AIV) was isolated from suspected broiler flocks and characterized using RT-PCR and sequencing techniques which have shown new interesting mutations as compared to previously characterized Tunisian strains of major clinical importance. Reverse transcription-PCR, nucleotide sequencing, and GenBank BLAST database analyses of external and internal genes of the virus demonstrated that the new isolate, designated $A / C K / T U N / 145 / 12$, has the ${ }^{333} P_{S R S S R}{ }^{*} \operatorname{SLF}^{341}$ motif at the cleavage site of its hemagglutinin (HA), different from that described in the older Tunisian strains, which possess the motif ${ }^{33}{ }^{3} P A R S S R{ }^{*} G^{2}{ }^{34}$, and others reported strains in the world. The presence of Leu at position 234 in the amino acid sequence of HA indicated the virus binding preference to the human cellular receptor $\alpha-2,6$ sialic acid. Besides, such HA amino acid sequence showed two new mutations D280N and Y144S. The hemadsorption (HB) site of its neuraminidase (NA) did show three new mutations H441N, N342D and S331N in comparison to older Tunisian strains. Such mutations were reported for the highly pathogenic H5N2 subtype in Nigeria. Phylogenetic data allowed classification of the new Tunisian isolate in a new genetic group including the old Tunisian isolates.
\end{abstract}

Keywords: Characterization; Epidemiology; Phylogeny; Influenza virus

\begin{abstract}
Abbreviations: AA: amino acid; AIV: Avian Influenza Virus; HA: Hemagglutinin; HB: Hemadsorption; HPAIV: High Pathogenic Avian Influenza Virus; LPAIV: Low Pathogenic Avian Influenza Virus; M: Matrix; NA: Neuraminidase; NP: Nucleoprotein; NS: Non Structural; PB2: Polymerase; PL: PDZ Ligand; RBS: Receptor Binding Site; RBD: RNA Binding Domain.
\end{abstract}

\section{Introduction}

The poultry sector is becoming an increasingly important agriculture sector, in Tunisia, This sector faces tough challenges due to viral infections in the region [1,2]. Influenza A viruses (IAV) belonging to the Orthomyxoviridae family, cause highly contagious respiratory diseases in chickens, leading to important economic losses related to mortality, severe egg drop and poor egg quality. The viral genome is a negative stranded RNA, made up of eight gene segments. These viruses have been divided in low pathogenic AI (LPAI) and high pathogenic AI (HPAI), on the basis of their capability to cause mild or severe disease in vulnerable birds, respectively. The subtypes H5, H7 and H9 cause respiratory and systemic diseases. The H9N2 subtype virus may infect chickens, turkeys, ducks and pigs and suspected to infect humans [3].

Phylogenetic analyses showed that avian $\mathrm{H} 9 \mathrm{~N} 2$ viruses are classified into three diverse groups: G1-like lineage, represented by G1 97, Y280like lineage, represented by Y280 or A/Chicken/Beijing/1/94 (BJ 94) and Y439-like lineage, represented by A/Duck/Hong Kong/Y439/97 (Y439) [4]. Since 1998, a new common lineage of H9N2 viruses in eastern China is represented by the A/Chicken/Shanghai/F/98 lineage (F 98-like lineage) [5].

In Tunisia, where poultry industry is of great importance for its social and economic impacts, active surveillance of avian H9N2 virus and study of strain evolution is a great importance to effectively control the disease. The epizootiology of AIV in Tunisia is being documented. The disease has been reported since 2009 and the virus is still circulating causing severe economical losses. Thus, efforts are undertaken to better control the disease by isolating and typing AIV field strains that are very important not only for the study of emerging viruses and their evolution but also for adaptation of preventive measures.

\section{Materials and Methods}

\section{Virus isolation}

The H9N2 avian influenza virus was isolated and identified in 2012 during an avian influenza (AI) outbreak in the south of Tunisia. At least 10 cloacae and 10 trachea swab samples were collected from suspected chickens. Initial isolation was performed in 10-day-old specific-pathogen-free embryonated chicken eggs (ECE, inoculated via the allantoic route and incubated at $37^{\circ} \mathrm{C}$ for $72-96 \mathrm{~h} \mathrm{[6]}$.

\section{Hemagglutination inhibition test}

Specific anti-H9N2 serum was prepared in chickens vaccinated with inactivated influenza vaccine (Nobilis H9N2-Intervet). Collected serum was titrated before its use in an inhibition hemagglutination test to confirm the identity of the isolated virus. The serum was heat treated at $56^{\circ} \mathrm{C}$ for $30 \mathrm{~min}$ and serially diluted in PBS (pH 7.4) in 96-well plate before adding an equal amount of $4 \mathrm{HA}$ units $(25 \mu \mathrm{l})$ of A/Chicken/ Tunisia/145/12 (H9N2) influenza virus in each well. After incubation for $30 \mathrm{~min}$ at room temperature, $25 \mu \mathrm{l}$ of $1 \%$ chicken red blood cells were added to each well and the plate incubated for $30 \mathrm{~min}$. A complete inhibition of hemagglutination indicates the identity of the virus tested (Table 1).

\section{Viral nucleic acid extraction}

Viral RNA was extracted using $200 \mu$ l of virus suspension following the Trizol method (Invitrogen, CA). The RNA was precipitated with

*Corresponding author: Rim Aouini, Laboratory of Epidemiology and Veterinary Microbiology, Institut Pasteur de Tunis, University of Tunis El Manar, 1002 TunisBelvedere, Tunisia, Tel: +21658954707; E-mail: rim_aouini@yahoo.fr

Received November 30, 2016; Accepted December 05, 2016; Published December 06, 2016

Citation: Aouini R, Laamiri N, Ghram A (2016) Novel Gene Mutations in Tunisian Isolate of Avian H9N2 Influenza Virus. J Vet Sci Technol 8: 405. doi: 10.4172/21577579.1000405

Copyright: (C 2016 Aouini R, et al. This is an open-access article distributed under the terms of the Creative Commons Attribution License, which permits unrestricted use, distribution, and reproduction in any medium, provided the original author and source are credited. 
absolute ethanol, centrifuged and the final pellet suspended in $20 \mu \mathrm{l}$ RNase-free water then stored at $-80^{\circ} \mathrm{C}$.

\section{Viral RNA amplification}

Two step RT-PCR techniques were carried out to amplify well defined regions of the six gene segments using segment-specific primers. The cDNA was synthesized using appropriate upstream primers with SuperScript ${ }^{\text {tw }}$ II Reverse transcriptase (Invitrogen, CA) then amplified by PCR using a mixture made of $5 \mu \mathrm{l}$ of cDNA, $2.5 \mu \mathrm{l}$ of $10 \times$ PCR buffer, $2.5 \mu \mathrm{l}$ of $2.5 \mathrm{mM}$ dNTPs, $0.5 \mu \mathrm{l}$ Taq DNA polymerase (5 units/ $\mu$ l, Invitrogen), $1 \mu \mathrm{l}$ of each primer (10 $\mu \mathrm{M}$ each) (Table 2$)$ [7], $2 \mu \mathrm{l}$ of $5 \mathrm{Mm} \mathrm{MgCl}_{2}$ (Invitrogen, CA) and $17.5 \mu \mathrm{l}$ RNase free water (BioBasic, CA). The PCR program was run as follows: $45^{\circ} \mathrm{C}$ for $30 \mathrm{~min}$, $95^{\circ} \mathrm{C}$ for $10 \mathrm{~min}, 40$ cycles of $95^{\circ} \mathrm{C}$ for $60 \mathrm{~s}, 58^{\circ} \mathrm{C}$ for $20 \mathrm{~s}\left(62^{\circ} \mathrm{C}\right.$ for $\mathrm{HA} 1$, $\mathrm{NA}, \mathrm{PB} 2$, and NS), $72^{\circ} \mathrm{C}$ for $1 \mathrm{~min}$ followed by $72^{\circ} \mathrm{C}$ for $10 \mathrm{~min}$. The obtained PCR products were purified with QIA quick PCR purification kit (Qiagen).

\section{Sequencing}

The purified PCR products were then partially sequenced using Amersham ET Dye terminator kit and analyzed with ABI 3730 DNA sequencer (Perkin-Elmer Applied Biosystems).

\section{Sequencing analyses}

The Bio-Edit program 5.0.6 software and the ClustalW alignment algorithm (Version 1.83) were used to compare and align nucleotide sequences. Phylogenetic trees were constructed by MEGA5.01 program, version 3.65 , with the neighbor-joining method using a grouping strength of 1000 bootstrap resembling. The Blast software and the Bio-Edit program were utilized to determine the sequence similarity between the Tunisian identified strains. The nucleotide sequences obtained were deposited in the GenBank data library under the accession numbers: KP058446, KP058447, KP271003, KP271004, KP271005 and KP772312. The amino acid residues were numbered according to the $\mathrm{HA}$ sequences of $\mathrm{Qu} / \mathrm{HK} / \mathrm{G} 1 / 97$ (H9) with the GenBank accession number AF156378.

\section{Results}

\section{Identification of AI virus isolate}

The HA titer of the allantoic liquid of inoculated SPF embryonated chicken eggs was 512HA. The IH test allowed confirmation of the isolated virus as avian Influenza type A virus using a specific anti-H9N2 serum, showing a titer of $512 \mathrm{IH}$. The virus was further characterized using RT-PCR and sequencing.

\section{Phylogenetic analysis of surface genes of $\mathrm{H} 9 \mathrm{~N} 2$ virus}

To find out its genetic diversity, the isolated virus was amplified by RT-PCR and 6 out of its 8 gene segments were partially sequenced. These sequences were then aligned with different $\mathrm{H} 9$ viral sequences listed in the GenBank (Table 3).

The results showed that the viral HA gene was correlated to the Libyan and the Middle Eastern strains, especially A/Chicken/ Libya/13VIR7225-5/2013, A/Chicken/Israel/1548/2006, A/Chicken/ SaudiArabia582/2005, A/Chicken/Pakistan/47/2003. The HA and NA (neuraminidase) gene sequences showed high homology with Middle Eastern strains grouped in the G1 lineage, sharing the same ancestor with the isolate A/Quail/Hong Kong/G1/1997 (Table 4).

To study the evolutionary relationships between the new and the old Tunisian H9N2 isolates found in the Genbank (Table 3), phylogenetic analyses were carried out for the 6 considered viral gene segments (hemagglutinin (HA), neuraminidase (NA), polymerase (PB2), nucleoprotein (NP), matrix (M) and non structural (NS) genes) (Figures 1 and 2). The HA amino acid sequence of the newly identified strain A/Chicken/Tunisia/145/12 showed $95 \%$ to $99 \%$ concordance with that of other strains of the G1 lineage. Besides, the neuraminidase gene of this isolate (nucleotides 962 to 1372) clustered with the A/Qa/

\begin{tabular}{|c|c|c|c|}
\hline Virus Name & Abbreviation & Host & HA titre \\
\hline A/Chicken/Tunisia/145/12 & A/CK/TUN/145/12 & Chicken & $1 / 1024$ \\
\hline
\end{tabular}

Table 1: H9N2 virus isolated from infected chickens in Tunisia 2012.

\begin{tabular}{|c|c|c|c|c|c|}
\hline Name & Sequence $\left(5^{\prime}-3^{\prime}\right)$ a & Position & $\begin{array}{l}\text { Expected } \\
\text { products } \\
\text { Size (pb) }\end{array}$ & Gene & Reference \\
\hline AMF & CTTCTAACCGAGGTCGAAAC & $7-26$ & 244 & M & \\
\hline AMR & AGGGCATTTTGGACAAAKCGTCTA & $259-238$ & & M & 20 \\
\hline MF & CTCATGGAATGGCTAAAGACA & $149-169$ & 700 & M & \\
\hline MR & CGATCAADAATCCACAATATC & $847-827$ & & M & 22 \\
\hline H9F & GAATCCAGATCTTTCCAGAC & $426-445$ & 384 & $\mathrm{HA}$ & \\
\hline H9R & CCATACCATGGGGCAATTAG & $808-789$ & & $\mathrm{HA}$ & 23 \\
\hline NPF & CAGRTACTGGGCHATAAGRAC & $1200-1220$ & 326 & NP & \\
\hline NPR & GCA TTGTCTCCGAAGAAATAAG & $1529-1510$ & & NP & 24 \\
\hline HAF1 & GAATTGATTATTATTGGTCAGTA & $710-732$ & 550 & $\mathrm{HA}$ & \\
\hline HAR1 & TCATCAATCT-TATTGTTGATCAT & $1272-1249$ & & $\mathrm{HA}$ & 25 \\
\hline NAF & CTTGTTGGCGACACACCAAGRAA & $961-983$ & 410 & NA & \\
\hline NAR & GAGCCTGTTCCAT-AGGTACCTGA & $1370-1348$ & & NA & 25 \\
\hline PB2F & TATTCAT-CRTCAATGATGTGGGA & $1591-1613$ & 540 & PB2 & \\
\hline PB2R & GATGCTYAATGCTGGTCCATATC & $2130-2108$ & & PB2 & 25 \\
\hline NSF & AGCAAAAGCAGGGTGACAAA & $1-20$ & 890 & NS & \\
\hline NSR & AGTAGAAACAAGGGTGTTTT & $890-871$ & & NS & 26 \\
\hline
\end{tabular}

aCodes for mixed bases positions: $D=G / A / T, H=A / C / T, K=G / T, R=A / G, Y=C / T$.

Table 2: Primer sequences as used in the RT-PCR. 
Citation: Aouini R, Laamiri N, Ghram A (2016) Novel Gene Mutations in Tunisian Isolate of Avian H9N2 Influenza Virus. J Vet Sci Technol 8: 405. doi: $10.4172 / 2157-7579.1000405$

Page 3 of 9

\begin{tabular}{|c|c|c|c|c|c|c|c|}
\hline References strains & Abbreviations & HA & NA & PB2 & NP & M & NS \\
\hline A/Chicken/Tunisia/145/12 & $\mathrm{Ck} / \mathrm{TUN} / 145 / 12$ & KP058446 & KP058447 & KP271005 & KP271003 & KP271004 & KP772312 \\
\hline A/chicken/Tunisia/848/2011 & $\mathrm{Ck} / \mathrm{TUN} / 848 / 11$ & JQ952591.1 & JQ952595.1 & - & - & - & - \\
\hline A/turkey/Tunisia/2068/2010 & Ck/TUN/2068/2010 & JQ952589.1 & JQ952593.1 & - & - & - & - \\
\hline A/chicken/Tunisia/2019/2010 & Ck/TUN/2019/2010 & JQ952588.1 & JQ952592.1 & - & - & - & - \\
\hline A/chicken/Tunisia/345/2011 & Ck/TUN/345/2011 & JQ952590.1 & JQ952594.1 & - & - & - & - \\
\hline $\mathrm{A} /$ migratory bird/Tunisia/51/2010 & MB/TUN/51/10 & JF323007.2 & JF323009.2 & JF323011.2 & JF323013.2 & JF323015.1 & KF751661.1 \\
\hline A/chicken/Tunisia/12/2010 & Ck/TUN/12/2010 & $\underline{\mathrm{JF} 323006.2}$ & JF323008.2 & JF323010.2 & JF323012.2 & JF323014.1 & JF323016.1 \\
\hline A/chicken/Libya/13VIR7225-5/2013 & CkLi13VIR7225513 & $\underline{\mathrm{KM} 244121.1}$ & - & - & - & - & - \\
\hline A/chicken/lsrael/1548/2006 & Ckls14806 & FJ464729.1 & - & - & - & FJ464611.1 & - \\
\hline A/chicken/Saudi Arabia/582/2005 & AvSA58205 & JX273556.1 & - & - & - & - & - \\
\hline A/avian/SaudiArabia/910135/2006 & AvSA91013506 & GU050287.1 & - & GU050294.1 & - & GU050288.1 & GU050291.1 \\
\hline A/chicken/Pakistan/47/2003 & CKPa4703 & $\underline{\mathrm{JX} 273552.1}$ & - & - & - & - & - \\
\hline A/chicken/lsrael/182/2008 & Ckls18208 & GQ120549.1 & - & - & - & - & - \\
\hline A/chicken/Egypt/D4907A/2012 & CkEgD4907A12 & $\underline{\mathrm{JX} 912984.1}$ & - & - & - & KF881678.1 & - \\
\hline A/quail/UnitedArabEmirates/1819/2006 & CkEmR181906 & - & $\underline{F 188376.1}$ & - & - & - & - \\
\hline A/chicken/Dubai/339/2001 & CkDu33901 & - & KF188354.1 & EF063556.1 & - & - & EF063542.1 \\
\hline A/chicken/Dubai/383/2002 & CkDu38302 & - & EF063522.1 & EF063557.1 & - & - & EF063543.1 \\
\hline A/chicken/Dubai/339/2001 & CkDu33901 & - & EF063521.1 & KF188349.1 & - & - & EF063542.1 \\
\hline A/Hong Kong/1074/1997 & QuHKG197 & AF156378 & GU053180.1 & AJ289872.1 & AF255743.1 & - & - \\
\hline
\end{tabular}

airuses whose HA, NA, PB2, NP, M and NS genes were sequenced in the present study; N.D, not done; $b$, - No sequence data available

Table 3: Abbreviations used and GenBank accession numbers for H9N2 Avian Influenza virus isolates included in the phylogenetic analyses.

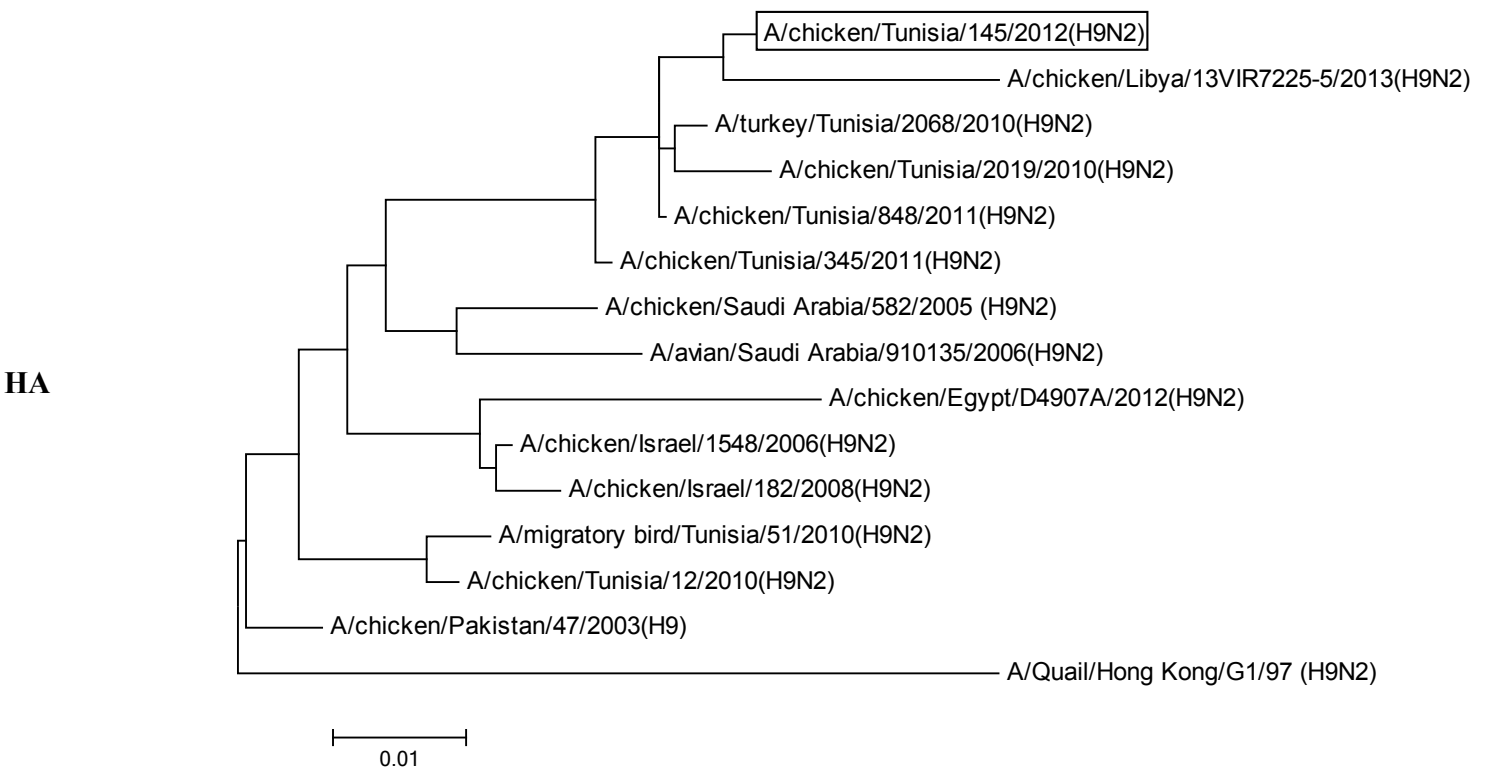

Figure 1: Phylogenetic Analysis of HA gene (878 bp from 392 to 1270) of Tunisian H9N2 virus and established Middle Eastern strains. The Tunisian isolate is framed.

HK/G1/97 lineage, as did isolates from Dubai, Hong Kong and United Arab Emirates.

\section{Phylogenetic analyses of internal genes}

Four internal genes (PB2, NP, M and NS) of the Tunisian H9N2 strain showed more than $91 \%$ nucleotide similarity with those of the Middle-Eastern strains isolated in 1997 and 2011 (Table 4). Phylogenetic studies of PB2 gene, using a 540- base-long nucleotide sequence (nucleotides 1591 to 2130 ) that codes the $\mathrm{PB} 2$ protein region between positions 530 and 710 , showed a close similarity between the A/Ck/TUN/145/12 and the old Tunisian strains which have close relationship with the Middle Eastern isolates (more than 93\% identity) (Figure 3).

Analysis of NP gene of A/Ck/TUN/145/12 allowed its classification in the same genetic group as the old Tunisian genotypes (Figure 4), showing a percentage of similarity of 98 to $97 \%$ with $\mathrm{A} / \mathrm{Hong}$ Kong/1074/99 (H9N2) and A/chicken/China/27402/1997 (H5N1), respectively (Table 4 ).

The matrix gene (regions of the overlapping reading frames of M1-M2, nucleotides 7 to 845 ) of A/Ck/TUN/145/12 strain (Figure 5) 
Citation: Aouini R, Laamiri N, Ghram A (2016) Novel Gene Mutations in Tunisian Isolate of Avian H9N2 Influenza Virus. J Vet Sci Technol 8: 405. doi: 10.4172/2157-7579.1000405

Page 4 of 9

NA

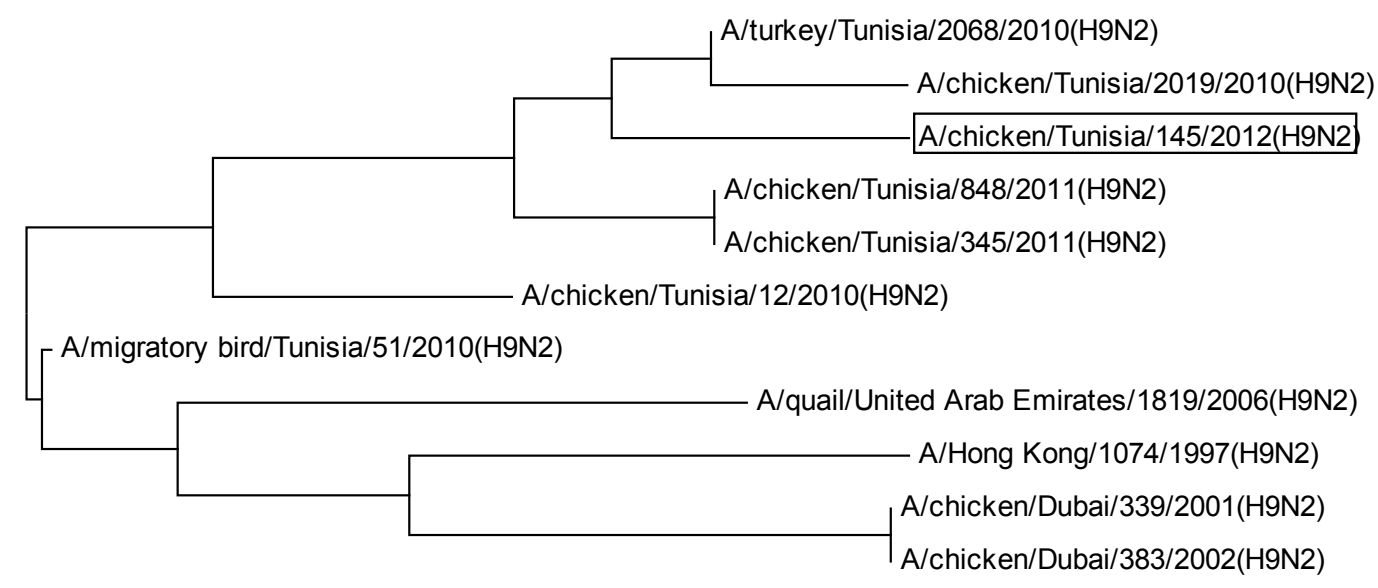

$\longmapsto .005$

Figure 2: Phylogenetic Analysis of NA gene (410 bp from 962 to 1372) of Tunisian H9N2 virus and established Middle Eastern strains. The Tunisian isolate is framed.

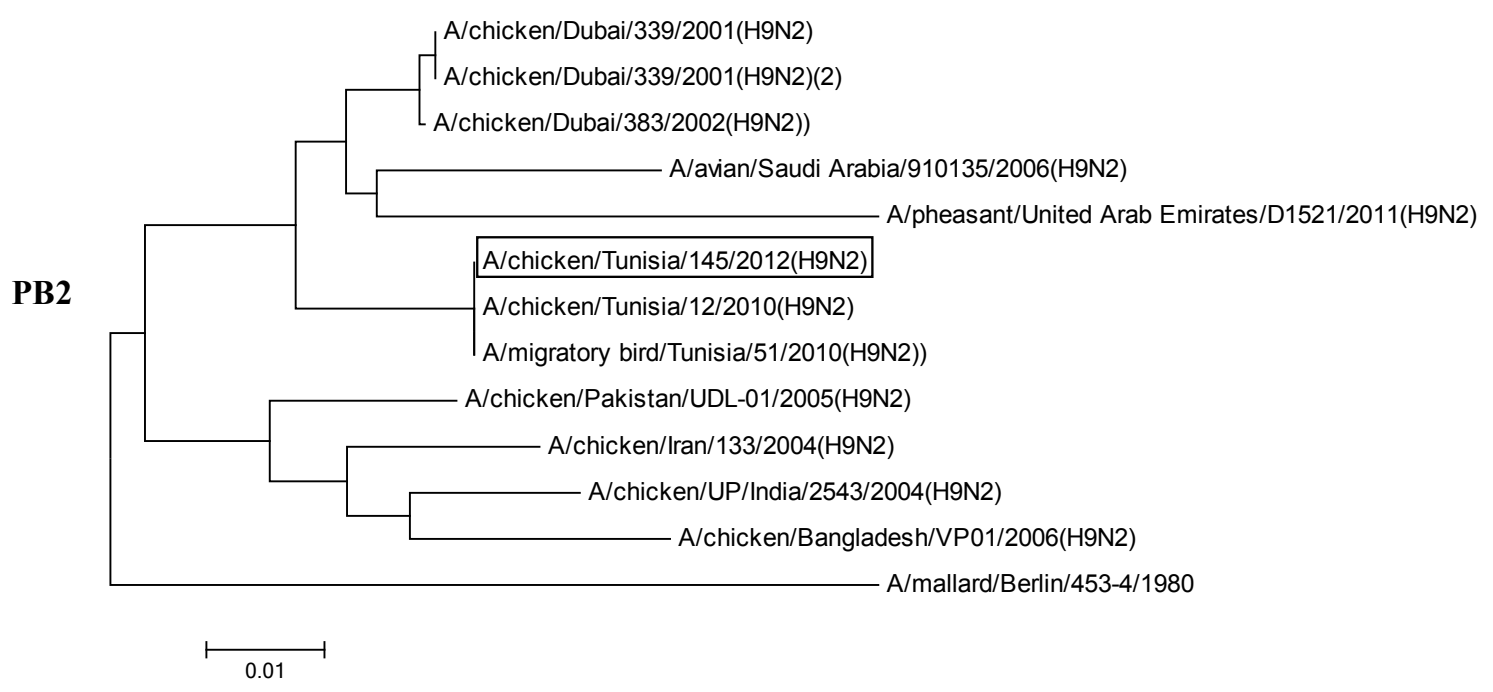

Figure 3: Phylogenetic Analysis of PB2 gene (540 bp from 1591 to 2130) of Tunisian H9N2 virus and established Middle Eastern strains. The Tunisian isolate is framed.

showed a close relationship with that of Middle Eastern isolates ( $96 \%$ to 98\% similarity) and full identity with the Tunisian isolates previously identified. It has also demonstrated $96.93 \%$ and $96 \%$ similarities with other subtypes like A/Ck/KHNC/100/04 (H7N3) and A/Environment/ Hong Kong/258/1997 (H5N1) strains, respectively.

The NS gene (nucleotides 1591 to 2130 ) of $\mathrm{Ck} / \mathrm{TUN} / 145 / 12$ strain demonstrated an evidence of a reassortment with other viral subtypes, showing $96 \%$ similarity with that of $\mathrm{A} / \mathrm{mallard} /$ Sweden/3240/2003(H8N4) strain (Figure 6).

\section{Genetic characteristics of surface glycoproteins}

Hemagglutinin: The molecular determinants of pathogenicity and virulence of influenza virus are the HA1/HA2 connecting (cleavage site) polypeptide sequence, the specific amino acid (aa) residues at the receptor binding site (RBS), and the presence or absence of glycosylation sites around the receptor binding site.

The HA cleavage site motif of the sequence of our isolate A/ $\mathrm{Ck} / \mathrm{TUN} / 145 / 12$ was ${ }^{333} \mathrm{PSRSSR}^{\star} \mathrm{GLF}^{341}$. Interestingly, this motif is different from that of other Tunisian H9N2 and Asian H9N2 viruses including those described in Libya, Israel, Pakistan, Saudi Arabia and Egypt which have the motif ${ }^{333}$ PARSSR $^{\star}$ GLF $^{341}$, meaning that our Tunisian isolate carries amino acid substitution in the cleavage site at position A334S.

Residues at positions 110,161,163,191, 198, 234, 235 and 236 are known to be the major components of the receptor binding site of HA molecule [6]. Our isolate showed conservation of residues P110, W161, T163, H191, A198 and I235 in the receptor binding pocket in comparison with those of the old Tunisian isolates and other isolates from all over the world. However, the left edge (amino acid residues at 


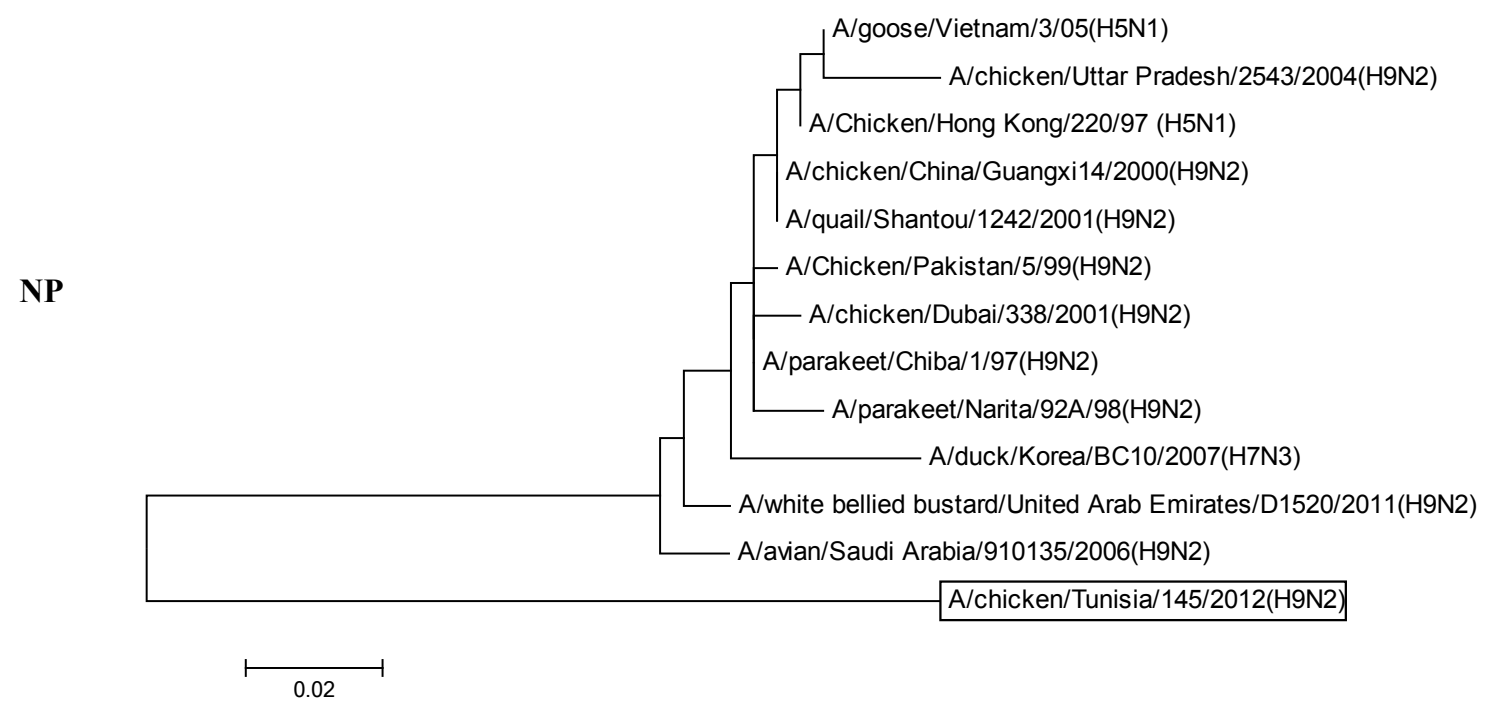

Figure 4: Phylogenetic Analysis of NP gene (326 bp from 1200 to 1529) of Tunisian H9N2 virus and established Middle Eastern strains. The Tunisian isolate is framed.

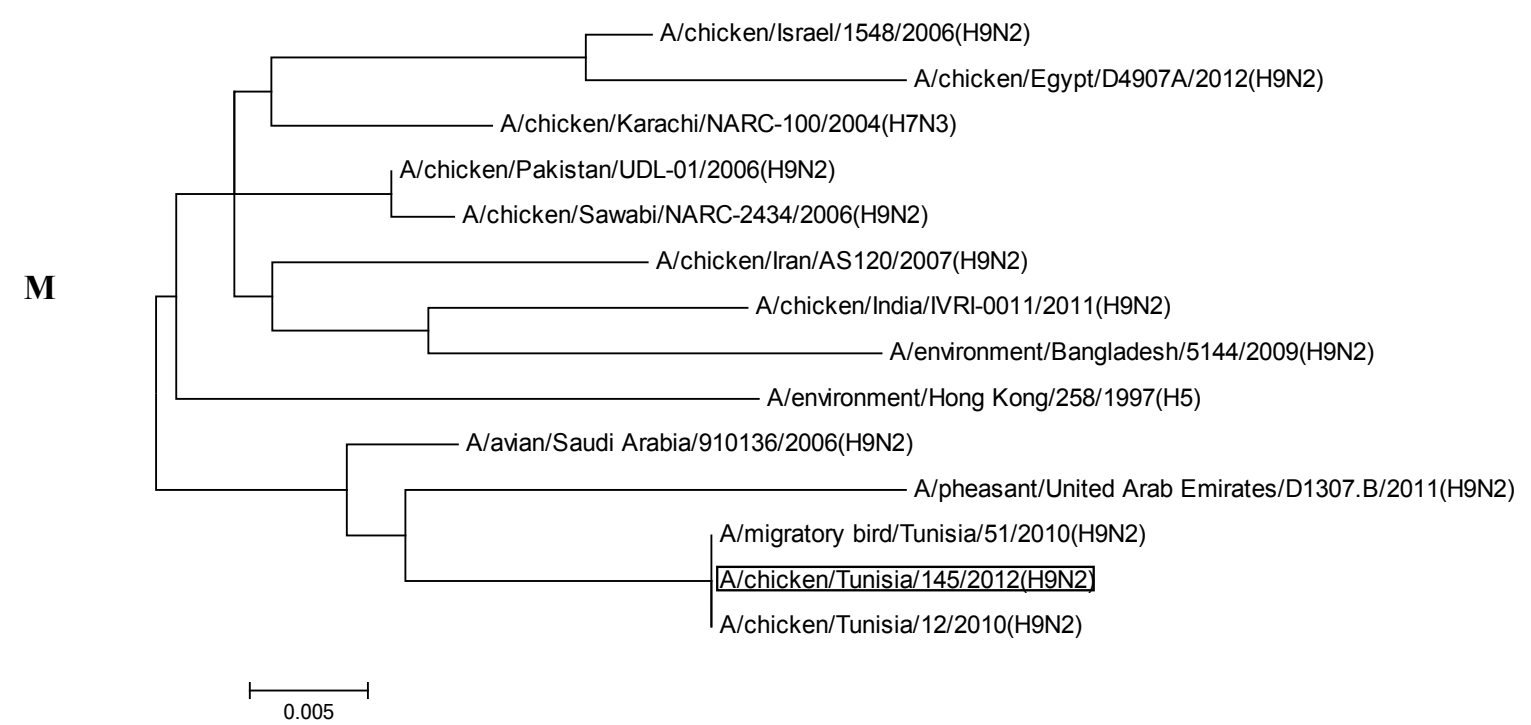

Figure 5: Phylogenetic Analysis of $\mathrm{M}$ gene (840 bp from 7 to 847 ) of Tunisian H9N2 virus and established Middle Eastern strains. The Tunisian isolate is framed.

positions 232-236) of the binding pocket motif was: NGLIG and the A/CK/TUN/145/12 H9N2 strain carried the amino acid substitutions (Y144S) and (D280N). The Y144 and D280 residues are shown to be engaged in both receptor binding and ligand interaction. Receptor mutations at this position (Y144S) showed dramatic impact on binding affinity and functionality [8].

Analysis of HA protein sequences indicated that the Tunisian H9N2 isolate has many potential glycosylation sites with an N-X-T/S motif (X can be any amino acid except Proline). In fact, $\mathrm{X}$ could be an S (Serine) at position 298-300 (NST) or any other substitutions as indicated in Table 5.

HB site of Neuraminidase: The HB site of neuraminidase is situated on the NA surface, far from the enzymatic site. Analysis of the neuraminidase and the framework sites of NA protein showed mutations in aa residues in the 3 loops that interact directly with the sialic acid. In the loop carrying amino acids at positions 367-370372, three S (Serine) were substituted by KLA, respectively; the new substitutions H441N, N342D and S331N were also found. On the other hand, the framework site contained R371, A372, N402, and E425 (Table 6). The Tunisian isolate presented the same mutations found in previously characterized Tunisian strains except for the three new mutations (H441N, N342D and S331N).

Molecular characteristics of internal proteins: The novel Tunisian H9N2 strain has shown the same $\mathrm{PB} 2, \mathrm{M}, \mathrm{NP}$ and NS protein sequences as the Tunisian isolates previously identified showing the same described mutations [9]. 
Citation: Aouini R, Laamiri N, Ghram A (2016) Novel Gene Mutations in Tunisian Isolate of Avian H9N2 Influenza Virus. J Vet Sci Technol 8: 405. doi: 10.4172/2157-7579.1000405

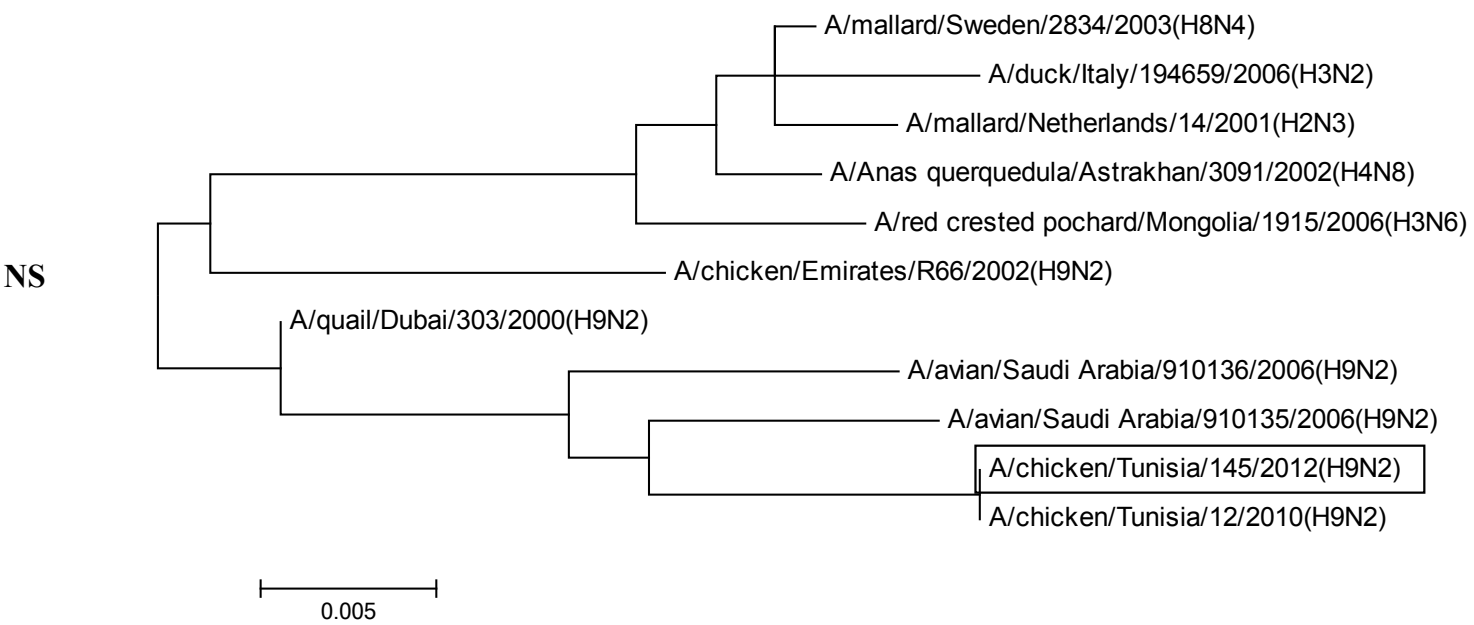

Figure 6: Phylogenetic Analysis of NS gene (890 bp from 1 to 890 ) of Tunisian H9N2 virus and established Middle Eastern strains. The Tunisian isolate is framed.

\begin{tabular}{|c|c|c|c|}
\hline Gene & Nucleotide similarity & $\%$ & Lineage \\
\hline PB2 & $\begin{array}{c}\text { A/chicken/Tunisia/12/2010(H9N2) } \\
\text { A/chicken/Dubai/338/2001(H9N2) } \\
\text { A/chicken/Dubai/383/2002 (H9N2) } \\
\text { A/quai//Dubai/303/2000(H9N2) } \\
\text { A/chicken/Pakistan/UDL-01/2005(H9N2) } \\
\text { A/chicken//ran/68/2006(H9N2) } \\
\text { A/environment/Bangladesh/8463/2010(H9N2) }\end{array}$ & $\begin{array}{l}100 \\
98 \\
97 \\
96 \\
95 \\
94 \\
93\end{array}$ & G1 \\
\hline HA & $\begin{array}{c}\text { A/chicken/Tunisia/848/2011(H9N2) } \\
\text { A/chicken/Libya/13VIR7225-5/2013(H9N2) } \\
\text { A/avian/Libya/RV35D/2006 (H9N2) } \\
\text { A/chicken/lsrael/1548/2006 (H9N2) } \\
\text { A/chicken/Pakistan/47/2003 (H9N2) }\end{array}$ & $\begin{array}{l}99 \\
98 \\
97 \\
96 \\
95\end{array}$ & G1 \\
\hline NP & $\begin{array}{c}\text { A/chicken/Tunisia/12/2010(H9N2) } \\
\text { A/Hong Kong/1074/99(H9N2) } \\
\text { A/chicken/China/27402/1997(H5N1) }\end{array}$ & $\begin{array}{l}100 \\
98 \\
97\end{array}$ & G1 \\
\hline NA & $\begin{array}{c}\text { A/chicken/Tunisia/2019/2010(H9N2) } \\
\text { A/chicken/Tunisia/848/2011(H9N2) } \\
\text { A/chicken/Tunisia/12/2010(H9N2) } \\
\text { A/migratory bird/Tunisia/51/2010 (H9N2) } \\
\text { A/quail/United Arab Emirates/1819/2006 (H9N2) } \\
\text { A/white bellied bustard/United Arab Emirates/D1520/2011 } \\
\text { A/quail/Shantou/1912/2001 } \\
\text { A/Hong Kong/1074/1997(H9N2) } \\
\text { A/quai//Shantou/308/2003 (H9N2) } \\
\text { A/chicken//ran/450/2001(H9N2) }\end{array}$ & $\begin{array}{l}99 \\
98 \\
96 \\
95 \\
94 \\
93 \\
92 \\
92 \\
91 \\
91\end{array}$ & G1 \\
\hline M & $\begin{array}{c}\text { A/migratory bird/Tunisia/51/2010(H9N2) } \\
\text { A/chicken/Tunisia/12/2010(H9N2) } \\
\text { A/avian/Saudi Arabia/910135/2006(H9N2) } \\
\text { A/chicken/Karachi/NARC-100/2004(H7N3) } \\
\text { A/chicken/India/IVRI-0011/2011(H9N2) }\end{array}$ & $\begin{array}{l}100 \\
100 \\
98 \\
97 \\
96\end{array}$ & G1 \\
\hline NS & $\begin{array}{c}\text { A/chicken/Tunisia/12/2010(H9N2) } \\
\text { A/avian/Saudi Arabia/910135/2006(H9N2) } \\
\text { A/chicken/Emirates/R66/2002(H9N2) } \\
\text { A/mallard/Sweden/3240/2003(H8N4) }\end{array}$ & $\begin{array}{l}100 \\
98 \\
97 \\
96\end{array}$ & G1 \\
\hline
\end{tabular}

Table 4: Similarity indices of the Tunisian H9N2 (A/CK/TUN/145/12) genes at the nucleotide levels. 


\begin{tabular}{|c|c|c|c|c|c|c|c|c|c|c|}
\hline Virus & $\begin{array}{l}\text { RBS } \\
110\end{array}$ & $\begin{array}{l}\text { RBS } \\
161\end{array}$ & $\begin{array}{l}\text { RBS } \\
163\end{array}$ & $\begin{array}{l}\text { RBS } \\
191\end{array}$ & $\begin{array}{c}\text { RBS } \\
198\end{array}$ & $\begin{array}{l}\text { RBS } \\
202\end{array}$ & $\begin{array}{l}\text { RBS } \\
203\end{array}$ & $\begin{array}{c}\text { Left-edge of Binding } \\
\text { pocket } 232-236\end{array}$ & $\begin{array}{l}\text { Connecting peptide aa } \\
\text { sequence } 152333\end{array}$ & $\begin{array}{c}\text { Glycosylation site at } \\
\text { position } 338168\end{array}$ \\
\hline A/Ck/TUN/145/12 & $P$ & W & $\mathrm{T}$ & $\mathrm{H}$ & A & $\mathrm{L}$ & $\mathrm{Y}$ & NG L IG & PSRSSR & + \\
\hline A/Ck/TUN/12/2010 & $\mathrm{P}$ & W & $\mathrm{T}$ & $\mathrm{H}$ & A & L & Y & NG L IG & P A R S S R & + \\
\hline A/Ck/TUN/345/2011 & $\mathrm{P}$ & W & $\mathrm{T}$ & $\mathrm{H}$ & A & L & $\mathrm{Y}$ & NG L IG & PARSSR & + \\
\hline A/Tu/TUN/2068/2010 & $\mathrm{P}$ & W & $\mathrm{T}$ & $\mathrm{H}$ & A & L & $\mathrm{Y}$ & NG L IG & P A R S S R & + \\
\hline A/Av/Libya/13VIR7225-5/2013 & $\mathrm{P}$ & W & $\mathrm{T}$ & $\mathrm{H}$ & A & $L$ & $\mathrm{Y}$ & NG L IG & P S K S S R & + \\
\hline A/Ck/lsrael/1548/2006 & $\mathrm{P}$ & W & $\mathrm{T}$ & $\mathrm{H}$ & $\mathbf{T}$ & L & $\mathrm{Y}$ & NG L IG & PARSSR & + \\
\hline A/Av/SA/582/2005 & $P$ & W & $T$ & $\mathrm{H}$ & $\mathrm{T}$ & L & $\mathrm{Y}$ & NG L IG & PARSSR & + \\
\hline A/Av/SA/910135/2006 & $P$ & W & $\mathrm{T}$ & $\mathrm{H}$ & A & L & $\mathrm{Y}$ & NG L IG & PARSSR & + \\
\hline $\begin{array}{c}\text { A/Qu/HK/G1/97 } \\
\text { A/CK/TUN/848/2011 }\end{array}$ & $\begin{array}{l}\mathrm{P} \\
\mathrm{P}\end{array}$ & $\begin{array}{l}W \\
W\end{array}$ & $\begin{array}{l}\mathrm{T} \\
\mathrm{T}\end{array}$ & $\begin{array}{l}\mathrm{H} \\
\mathrm{H}\end{array}$ & $\begin{array}{l}\mathbf{E} \\
\mathbf{A}\end{array}$ & $\begin{array}{l}\mathrm{L} \\
\mathrm{L}\end{array}$ & $\begin{array}{l}Y \\
Y\end{array}$ & $\begin{array}{l}\text { ND LQG } \\
N G L I G\end{array}$ & $\begin{array}{l}\text { PARSSR } \\
\text { PARSSR }\end{array}$ & $\begin{array}{l}+ \\
+\end{array}$ \\
\hline A/CK/TUN/51/2010 & $P$ & W & $\mathrm{T}$ & $\mathrm{H}$ & A & L & $\mathrm{Y}$ & NGQIG & PA R S S R & + \\
\hline A/Ck/Pak/47/2003 & $P$ & W & $\mathrm{T}$ & $\mathrm{H}$ & A & L & $\mathrm{Y}$ & NG L IG & PARSSR & + \\
\hline A/Ck/ls/182/2008 & $P$ & W & $\mathrm{T}$ & $\mathrm{H}$ & $\mathrm{T}$ & L & $\mathrm{Y}$ & NG L IG & PARSSR & + \\
\hline A/Ck/Eg/D4907A/2012 & $P$ & W & $\mathrm{T}$ & $\mathrm{H}$ & $A$ & L & $\mathrm{Y}$ & NG L IG & P A R S S R & + \\
\hline
\end{tabular}

$-/+$ absence or presence of the glycosylation site.

Table 5: Analysis of the amino acid sequences of the HA protein of the Tunisian isolate A/Ck/TUN/145/12 in comparison with old Tunisian and reference strains.

\begin{tabular}{|c|c|c|c|c|}
\hline Virus & $\begin{array}{c}\text { Neuraminidase } \\
\text { active } \\
\text { site }(\mathrm{HB}) \\
366.373\end{array}$ & $\begin{array}{c}\text { Framework } \\
\text { Site NA } \\
399.406\end{array}$ & $\begin{array}{c}\text { Framework } \\
\text { Site NA } \\
431.433\end{array}$ & $\begin{array}{c}\text { Framework } \\
\text { Site NA } \\
425\end{array}$ \\
\hline A/Ck/TUN/145/2012 & IKKDLRAG & DSDNWSGY & PKE & $E$ \\
\hline A/Ck/TUN/2019/2010 & IKKDLRAG & DSDNWSGY & PKE & $E$ \\
\hline A/Tu/TUN/2068/2010 & IKKDLRAG & DSDNWSGY & PKE & $E$ \\
\hline A/Ck/TUN/848/2011 & IKKDLRAG & DRDDWSGY & PKE & $E$ \\
\hline A/Ck/TUN/345/2011 & IKKDLRAG & DRDDWSGY & PKE & $E$ \\
\hline A/Ck/TUN/12/2010 & IKKDLRAG & DSDNWSGY & - & - \\
\hline A/MB/TUN/51/2010 & IKKDLRAG & DSDNWSGY & PQE & $E$ \\
\hline $\mathrm{A} / \mathrm{Ck} / \mathrm{Du} / 339 / 2001$ & IKKDLRAG & DS - - . - & $P Q E$ & $E$ \\
\hline $\mathrm{A} / \mathrm{Ck} / \mathrm{Du} / 338 / 2002$ & IKKDLRAG & DSDNWSGY & $P Q E$ & - \\
\hline A/Ck/Em/1819/2006 & IKEDLRAG & DSDNWSGY & PQE & $E$ \\
\hline A/Ck/HK/1074/1997 & IKKDSRAG & DSDNWSGY & PQE & $E$ \\
\hline
\end{tabular}

$(-)=$ gap

Table 6: Analysis of the amino acid sequences of the NA protein of the Tunisian isolate in comparison with older Tunisian and reference strains.

\section{Discussion}

The study of the six genes of Tunisian H9N2 subtype of avian influenza reported, for the first time, new mutations that are not found in previously described Tunisian strains. Considering the sequences and the phylogeny analyses of Middle Eastern and older Tunisian viruses, it appeared that they are closely related and represent a single sub-lineage, the G1-like lineage, indicating similar origin. It might reflect geographical parameters responsible of virus restriction in these areas.

The genetic data of H9N2 subtype circulating in Tunisian poultry farms are presented. The results revealed that H9N2 virus infection is well established in many endemic areas of the country and allowed the characterization of our strain from a flock in southern of Tunisia. Thus, understanding the genetic and the biological characteristics of circulating H9N2 virus can give more comprehensive vision on the biology and the ecology of $\mathrm{H} 9 \mathrm{~N} 2$ virus, and the capacity of migratory birds to disperse AI viruses. Although infected birds might be able to spread the virus over short distances, during periods of cold weather, experiments in which birds are subjected to physiologic stresses associated with migration are needed to determine their capacity to spread virus over long distances. Indirect estimations of virus dispersal derived from knowledge of bird migrations could also provide complementary information related to the spread of avian influenza viruses [10].

The Blast analysis (NCBI) of the nucleotide sequences of HA and NA genes showed that $\mathrm{A} / \mathrm{Ck} / \mathrm{TUN} / 145 / 12$ is the closest strain (more than $92 \%$ identity) to the Middle Eastern isolates belonging to the G1like lineage of H9N2 subtype.

The results of phylogenetic analyses were totally in accordance with blast data, and confirmed that our isolate fall, along the Middle Eastern isolates, into one cluster in relation to the G1 lineage; a result that may indicate that both strains have the same origin.

Based on the deduced amino acid sequences, the HA1-HA2 connecting peptides of the Tunisian H9N2 isolate did not harbor multiple basic amino acids with the motif PSRSSR/GL which is not exactly as found for the newly isolated H9 viruses in Middle East, having the motif PARSSR/GL $[11,12]$. A new substitution of Alanine, a non polar amino acid, by Serine, a polar amino acid, at position 334 is noticed. The biological significance and the role of such substitution are not yet known. This may reveal the LPAI nature of H9N2 strain, despite a motif identical to the RX RYK-R required for the highly pathogenic $\mathrm{H} 5$ and $\mathrm{H} 7$ subtypes [13]; noting that such new mutation was also found in highly pathogenic H5N2 subtype in Nigeria [14]. 
These genetic results indicated that our H9N2 virus may have the capacity to acquire basic amino acids in HA connecting peptide sequence, required to become highly pathogenic through the addition of a single basic amino acid. Moreover, A/Ck/TUN/145/12 possesses a Leu (L) at position 234 in its HA1 portion; the receptor binding site (RBS) residue being essential for the transmission of the H9N2 viruses in ferrets $[13,15,16]$. Besides, Q234L substitution, found in G1 lineage isolated in Hong Kong, was shown to allow H9N2 viruses to infect non ciliated cells and to grow more efficiently in human airway epithelial cell cultures, resulting in the increase of the severity of human infection [13].

Antigenic and phylogenetic analyses of the Tunisian isolate demonstrated that its surface glycoproteins are related to those of A/ $\mathrm{Qa} / \mathrm{HK} / \mathrm{G} 1 / 97$ lineage, with the highest homology with $\mathrm{A} /$ chicken/ Libya/13VIR7225-5/2013(H9N2) (98\%), A/chicken/Israel/1548/2006 (96\%) and A/chicken/Pakistan/47/2003 (H9N2) (95\%) viruses. The two new mutations D280N and Y144S in HA gene and their significance are not yet known.

Three new mutations $\mathrm{H} 441 \mathrm{~N}, \mathrm{~N} 342 \mathrm{D}$ and S331N are found in NA gene. The N342D mutation was found in the NA gene of H1N1 and $\mathrm{H} 3 \mathrm{~N} 2$ avian influenza viruses in Japan $[14,15]$. This may indicate the capacity of H9N2 virus to pass to humans. Besides, a potential additional glycosylation site was discovered at position 331 of NA gene in A/CK/TUN/145/2012 (S331N mutation); such mutation was also detected in H5N2 Nigerian isolate in 2007 [12]. The significance of $\mathrm{H} 441 \mathrm{~N}$ mutation is not known, yet. Therefore, all these new mutations may contribute to the change of a low pathogenic to a high pathogenic avian influenza $\mathrm{H} 9 \mathrm{~N} 2$ virus.

The Q432K substitution in NA gene is similar to that observed in other identified Tunisian strains. But, the biological meaning of this mutation is not known. All other mutations found in previous Tunisian strains are absent in A/CK/TUN/145/2012 isolate.

The E627K mutation in PB2 gene contributes to higher polymerase activity of influenza virus [4]. The PB2 E627K mutation has shown, in vitro, a promoting effect on virus growth in mammalian but not in avian cells [16]

The M1 protein showed a V15I substitution in all H9N2 lineages [17]. When the complete genome phenotypes of high-pathogenic strains were compared to those of low pathogenic ones, 5 amino acid differences were found and correlated with high-pathogenic strain phenotype. One of these changes was seen in M1 (V15I) of our strain, a change that has also been found in PR34 but not in Brevig18 strains [18].

Recently, NS1 protein of avian influenza A viral was shown to be a type I interferon (IFN) antagonist which plays a major role in viral pathogenesis [19]. Molecular analysis demonstrated that our isolates contain a NS1 protein with 230aa in length, typical of H9N2 viruses. In its RNA- binding domain of NS1, A/Ck/TUN/145/2012 isolate has incorporated R38 and K41 amino acids, which are shown to be critical for RNA binding. Similarly, amino acid residues P31, D34, R35, G45, R46, T49 and D55 also mediate NS1-dsRNA interaction and residue D55 is situated within the third alpha- helix (residues 54-70) of the dsRNA-binding domain RBD (residues 1-73) of NS1 [20]. However, NS1 D55G may stabilize the coiled-coiled helical structure. The old Ck/TUN/12/2010 Tunisian strain showed an Asp (N) at position 217 which is also found in our A/CK/TUN/145/12 strain but differs from other $\mathrm{H} 9 \mathrm{~N} 2$ strains, showing a $\mathrm{K}$ at this position. The biological significance of this substitution is not known yet. However, the Ck/ TUN/145/2012 isolate didn't show the five amino acid deletion
(80TIAS84) already described for avian strains isolated in 2001 in Hong Kong; their significance being still not understood [21]. Finally, our H9N2 Tunisian strain showed a PL motif "GSEV" as previously found in Tunisian strains isolated in 2010; the biological signification of this motif is not yet known [22]. Interestingly, the E227G mutation in NS1 introduces an S70I mutation into nuclear export protein.

\section{Acknowledgements}

This work was supported by the Institut Pasteur de Tunis and the Ministry of Higher Education and Scientific Research (LR11IP03).

\section{Disclosure}

There is no conflict of interest.

\section{References}

1. Bourogâa H, Hellal I, Hassen J, Fathallah I, Ghram A (2012) S1 gene sequence analysis of new variant isolates of avian infectious bronchitis virus in Tunisia. Vet Med Res Rep 3: 41-48.

2. Tombari W, Paul M, Bettaieb J, Larbi I, Nsiri J, et al. (2013) Risk factors and characteristics of low pathogenic avian influenza virus isolated from commercial poultry in Tunisia. PloS one 8: e53524.

3. Kang N, Chen M, Bi FY, Chen MM, Tan Y (2016) First Positive Detection of H9 Subtype of Avian Influenza Virus Nucleic Acid in Aerosol Samples from Live Poultry Markets in Guangxi, South of China. Chin Med J 129: 1371-1373.

4. Zhang H, Li X, Guo J, Li L, Chang C, et al. (2014) The PB2 E627K mutation contributes to the high polymerase activity and enhanced replication of H7N9 influenza virus. Journal General Virology 95: 779-786.

5. Xie Z, Pang YS, Liu J, Deng $X$, Tang $X$, et al. (2006) A multiplex RT-PCR for detection of type $A$ influenza virus and differentiation of avian $\mathrm{H} 5, \mathrm{H} 7$, and $\mathrm{H} 9$ hemagglutinin subtypes. Mol. Cell. Probes 20: 245-249.

6. Tombari W, Nsiri J, Larbi I, Guerin JL, Ghram A (2011) Genetic evolution of low pathogenicity H9N2 avian influenza viruses in Tunisia: acquisition of new mutations. Virol J 8: 467

7. Amir B, Wernery U, llyushina N, Webster RG (2007) Characterization of avian H9N2 influenza viruses from United Arab Emirates 2000-2003. Virology 361: 45-55.

8. Lundström L, Kuhn B, Beck J, Borroni E, Wettstein JG, et al. (2009) Mutagenesis and molecular modeling of the orthosteric binding site of the mGlu2 receptor determining interactions of the group II receptor antagonist H-HYDIA. Chem Med Chem 4: 1086-1094.

9. Homayounimehr AR, Dadras H, Shoushtari A, Pourbakhsh SA (2010) Sequenceand phylogenetic analysis of the haemagglutinin genes of H9N2 avian influenza viruses isolated from commercial chickens in Iran. Trop Anim Health Prod 42: 1291-1297.

10. Kilpatrick AM, Chmura AA, Gibbons DW, Fleischer RC, Marra PP, et al. (2006) Predicting the global spread of H5N1 avian influenza. Proc Natl Acad Sci 103 19368-19373.

11. Gaidet N, Cattoli G, Hammoumi S, Newman SH, Hagemeijer W, et al. (2009) Evidence of Infection by H5N2 Highly Pathogenic Avian Influenza Viruses in Healthy Wild Waterfowl. Plos Medicine 4: e1000127.

12. Haghighat Jahromi M, Asasi $K$, Nili H, Dadras $H$, Shooshtari AH (2008) Coinfection of avian influenza virus (H9N2 subtype) with infectious bronchitis live vaccine. Arch Virol 153: 651-655.

13. Wan H, Sorrell EM, Song H, Hossain MJ, Ramirez-Nieto G, et al. (2008) Replication and transmission of H9N2 influenza viruses in ferrets: evaluation of pandemic potential. PLoS ONE 3: e2923.

14. Dapat IC, Dapat C, Baranovich T, Suzuki Y, Kondo H, et al. (2012). Genetic Characterization of Human Influenza Viruses in the Pandemic (2009-2010) and Post-Pandemic (2010-2011) Periods in Japan. PloS one 7: e36455.

15. Dapat C, Suzuki Y, Kon M, Tamura T, Saito R, et al. (2010) Phylogenetic Analysis of an Off-Seasonal Influenza Virus A (H3N2) in Niigata, Japan. Jpn J Infect Dis 64: 237-241.

16. De Jong RM, Stockhofe-Zurwieden N, de Boer-Luijtze EA, Ruiter SJ, de Leeuw OS (2013) Rapid emergence of a virulent PB2 E627K variant during adaptation of highly pathogenic avian influenza H7N7 virus to mice. Virol J 10: 276 
Citation: Aouini R, Laamiri N, Ghram A (2016) Novel Gene Mutations in Tunisian Isolate of Avian H9N2 Influenza Virus. J Vet Sci Technol 8: 405. doi: 10.4172/2157-7579.1000405

Page 9 of 9

17. Jakhesara SJ, Bhatt VD, Patel NV, Prajapati KS, Joshi GC (2014). Isolation and characterization of H9N2 influenza virus isolates from poultry respiratory disease outbreak. Springer Plus 3: 196.

18. Perdue ML, García M, Senne Fraire M (1997) Virulence-associated sequence duplication at the hemagglutinin cleavage site of avian influenza viruses. Virus Res 49: 173-186.

19. Basler CF, Reid AH, Dybing JK, Janczewski TA, Fanning TG (2001) Sequence of the 1918 pandemic influenza virus nonstructural gene (NS) segment and characterization of recombinant viruses bearing the 1918 NS genes. Proc Natl Acad Sci 98: 2746-2751.
20. Wang W, Riedel K, Lynch P, Chien CY, Montelione GT, et al. (1999) RNA binding by the novel helical domain of the influenza virus NS1 protein requires its dimer structure and a small number of specific basic amino acids. RNA 5 195-205.

21. Long JX, Peng DX, Liu YL, Wu YT, Liu XF (2008) Virulence of H5N1 avian influenza virus enhanced by a 15 -nucleotide deletion in the viral nonstructural gene. Virus Genes 36: 471-480.

22. Agustin $P$, Digard $P(2002)$ The influenza virus nucleoprotein: a multifunctional RNA-binding protein pivotal to virus replication. J Gen Virol 83: 723-734. 